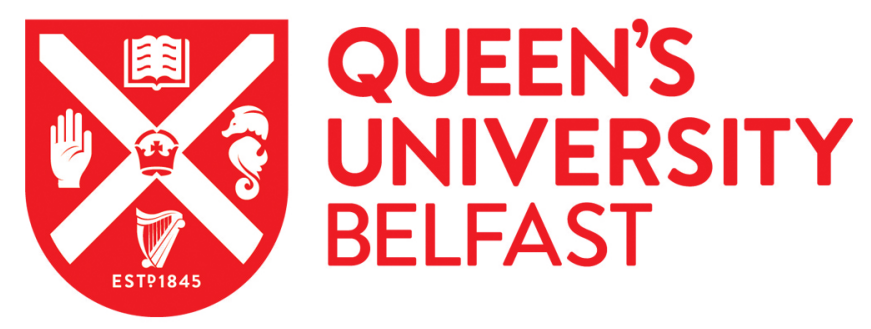

\title{
Impact of school-based educational interventions in middle adolescent populations (15-17yrs) on human papillomavirus (HPV) vaccination uptake and perceptions/knowledge of HPV and its associated cancers: A systematic review
}

Flood, T., Wilson, I. M., Prue, G., McLaughlin, M., \& Hughes, C. M. (2020). Impact of school-based educational interventions in middle adolescent populations (15-17yrs) on human papillomavirus (HPV) vaccination uptake and perceptions/knowledge of HPV and its associated cancers: A systematic review. Preventive Medicine, 139, [106168]. https://doi.org/10.1016/j.ypmed.2020.106168

Published in:

Preventive Medicine

Document Version:

Peer reviewed version

Queen's University Belfast - Research Portal:

Link to publication record in Queen's University Belfast Research Portal

\section{Publisher rights}

Copyright 2020 Elsevier.

This manuscript is distributed under a Creative Commons Attribution-NonCommercial-NoDerivs License

(https://creativecommons.org/licenses/by-nc-nd/4.0/), which permits distribution and reproduction for non-commercial purposes, provided the author and source are cited.

\section{General rights}

Copyright for the publications made accessible via the Queen's University Belfast Research Portal is retained by the author(s) and / or other copyright owners and it is a condition of accessing these publications that users recognise and abide by the legal requirements associated with these rights.

The Research Portal is Queen's institutional repository that provides access to Queen's research output. Every effort has been made to ensure that content in the Research Portal does not infringe any person's rights, or applicable UK laws. If you discover content in the Research Portal that you believe breaches copyright or violates any law, please contact openaccess@qub.ac.uk. 


\section{An exploration of the impact of school-based educational interventions in middle adolescent populations (15-17yrs) on HPV uptake and perceptions/knowledge of HPV and its associated cancers; a systematic review.}

\section{Abstract (unstructured):}

The American Academy of Paediatrics (AAP) divides adolescence into early (12-14 years), middle (15-17 years), and late (18-21 years) stages. School-based HPV educational interventions are largely directed at parents of early adolescents at the time of vaccination. As the average age of first sexual intercourse in high income countries is 15-17 years old, a second educational intervention for middle adolescents could have a strong impact on HPV prevention, providing an opportunity for self-consenting to HPV vaccination in many countries. This paper appraises literature exploring the impact of school-based educational interventions in 15-17 year olds, on HPV vaccination uptake and/or perceptions/knowledge of HPV and its associated cancers.

Randomised controlled trials (RCTs) and quasi-experimental designs (QEDs) (2007-2019) were included if they delivered a school-based educational intervention for 15-17 year olds, and the outcome measures included HPV vaccination uptake, knowledge of HPV and associated cancers or perception/attitude regarding self-protection against HPV.

Fifteen studies met the inclusion criteria and were assessed for quality using the Quality Assessment Tool for Quantitative Studies. All studies demonstrated a statistically significant improvement in at least one major outcome measure post-intervention, despite the wide range in design of interventions, though only three studies actually measured changes to HPV vaccination uptake. Stakeholder engagement was absent in most intervention designs and many were not grounded in evidenced theory. Content was largely focused on female cervical cancer, rarely discussing oropharyngeal cancer, the most pre-dominant HPV-associated cancer in men. An optimal mixed gender intervention remains to be established for middle adolescents.

Keywords: Human Papilloma Virus; HPV; education; adolescent; cancer; sexual risk behaviour; intervention; school-based 


\section{Background:}

Human papillomavirus (HPV) infection is the most common sexually transmitted infection of the reproductive tract ${ }^{1,2}$ with the highest incidence occurring among teenagers and young adults $\mathrm{s}^{3,4}$. HPV types 16 and 18 are associated with approximately $70 \%$ of cervical cancers ${ }^{5,6,7}$ and HPV is also associated with penile cancer in males alongside cancers of the anus and oesophagus in both women and men ${ }^{6,8,9}$. It is predicted that HPV-positive oropharyngeal cancer will soon become the most common HPVassociated cancer in the US with most cases occurring in males ${ }^{10}$.

Prophylactic HPV vaccines have been available for females for protection against HPV-associated cervical cancer since $2006^{11}$ with many countries also introducing vaccination programmes for males in recent years ${ }^{12}$. Merck's 9-valent HPV vaccine has the potential to prevent $90 \%$ of cervical, vulvar, vaginal, and anal cancers ${ }^{12}$.

Despite the implementation of HPV vaccination programmes in a growing number of countries, there is a huge disparity in the uptake of the vaccination worldwide with the UK having one of the highest uptakes and the US having one of the lowest rates of uptake ${ }^{9}$. Recently, some countries have seen uptake of the HPV vaccination fall due to safety concerns. For example, Denmark achieved initial vaccination rates of $80-90 \%{ }^{13}$, however, following escalation of public concern about possible side effects, based primarily on social and televised media information, this rate dropped to $23 \%$ in $2016^{14}$ recovering to $46 \%$ by $2017^{15}$. In 2013 , Japan's health ministry also decided to withhold its recommendation of the HPV vaccination because of public concerns ${ }^{15}$. Ireland also experienced a significant fall in vaccination uptake after initially achieving high levels when a patient advocacy group raised concerns about side-effects in adolescent females ${ }^{14,15}$. Despite safety concerns being addressed and dispelled ${ }^{16}$, this fluctuation highlights the importance of continuous re-enforcement of education regarding HPV vaccination to optimise vaccination uptake and improve HPV education in young people.

School-based education programmes have been very effective in producing significant positive changes in HPV knowledge and sexual behavior intentions ${ }^{9,17-19}$ though they typically involve 9-13 year old adolescents. As a consequence of this young age, educational HPV programmes have tended to focus on educating parents rather than students as parents are usually the primary decision-makers in this process for this age group ${ }^{20-24}$. Unfortunately, parents and education providers are often uncomfortable discussing sexual practices of adolescents ${ }^{25}$ and are often concerned that HPV vaccines increase sexual activity among adolescents although there is no evidence to support this notion ${ }^{5,26}$. Consequently, the majority of adolescents who receive the vaccination have low awareness and knowledge about the HPV virus, especially regarding cancer risks ${ }^{27}$. Lack of parental acceptance of HPV vaccinations has been identified as being one of the main barriers of higher vaccine uptake ${ }^{28,29}$.

Numerous countries report the average age of first sexual intercourse to be between 15-17 years old including the UK, France, Sweden, Nigeria, the US, Canada and Australia ${ }^{24,30-36}$ and therefore providing information regarding HPV risk is most relevant at this age, where adolescents are fundamentally more involved in decisions about their health and sexual practices ${ }^{9,37}$. Many economically developed countries, while providing the HPV vaccination, do not have national school-based programmes embedded in their curricula and therefore little information is provided regarding HPV at any point in the national school curriculum ${ }^{38,39,40}$. Consequently, it is estimated that adolescents 15-19 years old, still acquire $50 \%$ of all new STIs ${ }^{36,41}$ and are at the highest risk of contracting the HPV virus ${ }^{18,42}$. 
The aim of this systematic review is to assess the impact of school-based education interventions on HPV uptake and perceptions/knowledge of HPV and its associated cancers in 15-17 year old adolescents.

\section{Methodology:}

This systematic review was reported in accordance with the PRISMA (Preferred Reporting Items for Systematic Reviews and Meta-Analyses) guidelines and a protocol was registered with PROSPERO prior to the commencement of the review ${ }^{43}$. The search strategy, inclusion and exclusion criteria, study selection approach, evaluation of the quality of the studies, and data extraction process are described below.

\section{Search strategy:}

We conducted systematic searches of the following databases: Medline, EMBASE, Scopus, CINAHL, PsycInfo, PsycArticles, AMED and Cochrane Reviews. The PICO mnemonic - Population, Intervention, Comparison intervention, and Outcome measures - was used to establish search terms. The search strategy was based on using combinations of the following keywords and related index words: humanpapilloma virus; adolescent; uptake/education and randomised controlled trials/quasiexperiments/intervention. Although randomised controlled trials (RCTs) are the gold standard for inclusion in systematic reviews, the reviewers acknowledged that random assignment can be difficult or impossible in educational interventions ${ }^{44}$ and therefore included both RCTs and quasi-experimental design studies (QEDs) in this review.

Inclusion and Exclusion Criteria:

RCTs and QEDs were included where a school-based educational intervention was implemented which included any adolescents between the ages of 15-17 years and the measured outcome was at least one of the following: HPV vaccination uptake, knowledge of HPV and associated cancers or perception/attitude regarding self-protection against HPV.

Potentially eligible studies were screened by title and abstract to assess whether they met the inclusion criteria. As licensure of the first HPV vaccine was established in 2006, studies prior to 2007 were not included. Studies were retrieved until the end of 2019. Figure 1 demonstrates the process of this review; AMED and Cochrane review yielded no results from the search and therefore were not added to the flow diagram.

Figure 1

Full-text articles were excluded where the study population was either college/university students over 17 years or alternatively students who were 11-14 years old. One potentially eligible study was excluded due to its unavailability in English ${ }^{45}$. Another study was excluded as it was presented as a poster, lacking adequate detail to establish the quality of the study ${ }^{46}$. 
Evaluation of the quality of the studies and data extraction process:

For each eligible article, we systematically extracted data, based on an agreed-upon set of categories (by consensus of all authors). These categories included bibliographic information, study design, aims of study, study population, theory of intervention, intervention design, data collection timeline and statistically significant measured outcomes of the intervention (summarized in Table 1).

Table 1

The 'Quality Assessment Tool for Quantitative Studies' (QATQS) was used to assess the quality of the eligible articles. This instrument is widely established for use in the assessment of studies for systematic reviews related to sexual health, especially in the evaluation of public health programmes ${ }^{47,48}$. Its content and construct validity are well-established, consisting of 8 standardized criteria scored on a 3point scale corresponding to weak, moderate or strong with strong being the highest performing score $^{49}$. Two researchers independently scored each paper and consensus was reached within the research team where discrepancies occurred in the scoring.

\section{Results:}

\section{Study Characteristics:}

Our search yielded 15 school-based educational interventional studies of which 4 were RCTs and the remaining 11 studies were QEDs. Individual study quality was evaluated using the QATQS ${ }^{47,48}$, with 5 out of 15 studies being rated to be of high quality, 9 studies rated as being of moderate quality and the remaining 1 study rated as being of poor quality (see Table 2). Blinding was generally considered the lowest ranking criteria as a study was deemed 'weak' where blinding was not described. Confounders were also considered 'weak' where control and intervention group demographics were not clarified. Where withdrawal and dropout were not discussed, the study also received a 'weak' grading.

Table 2

Population profiles:

The 15 studies were conducted in a diverse range of countries including 3 from the US ${ }^{22,50,51}, 2$ from Sweden $^{3,52}, 2$ from Nigeria ${ }^{53,54}, 1$ from Germany ${ }^{55}, 1$ from Hungary $^{38}, 1$ from Australia ${ }^{8}$ and 1 from the $\mathrm{UK}^{56}$. The remaining 4 studies were from Asia including Singapore ${ }^{57}$, Taiwan ${ }^{28}$, Hong Kong ${ }^{37}$ and Malaysia ${ }^{58}$. Study sizes ranged considerably with the largest being Davies et al's ${ }^{8}$ study which included 6,965 students while Yoost et al. ${ }^{51}$ conducted a study with only 21 students completing all aspects of the study.

Outcome measures of Studies:

Post-intervention, all fifteen studies reported a statistically significant improvement in their specific outcome measures including changes in knowledge, attitude and perception with regard to HPV vaccination and associated cancer prevention. All of the studies aimed to improve knowledge related to 
HPV risk and HPV vaccination while many focused on improving positive attitudes/perceptions regarding self-protection against acquirement of HPV $3,8,22,28,37,38,51,52,57,58$.

Only 3 of the fifteen studies explored the actual effect of the intervention on HPV vaccination uptake ${ }^{3,8,51}$. Two of these studies by Davies et al. ${ }^{8}$ and Grandahl et al. ${ }^{3}$, were large, high quality studies, including males and females, whose RCT designs were based on established scientific theories. However, while Grandahl et al. ${ }^{3}$ found that HPV vaccination uptake rates increased to a higher degree in the intervention group, Davies et al. ${ }^{8}$ did not find any difference between their intervention and control groups. Davies et al. ${ }^{8}$ proposed that, due to the HPV vaccination coverage being so high in both groups ( $>85 \%$ uptake), this finding could be related to a possible ceiling effect. In contrast to this, Grandahl et al.' $s^{3}$ pre-intervention vaccination rate was only $52.5 \%$, increasing to $59 \%$ after the intervention. Yoost et al. ${ }^{51}$, using a pre-test/post-test quasi-experimental design, found HPV vaccine initiation or completion was $38 \%$ at the time of the session post-test. This report increased to $71.4 \%$ at 6 months among those who attended that session.

Six additional studies recorded 'intention to be vaccinated' against HPV after the intervention $22,28,37,38,56,57$. Four of the fifteen studies ${ }^{3,8,51,52}$ explored the impact of the intervention on sexual behavior intention including condom use. Nine of the studies also specifically aimed to improve cervical cancer prevention, knowledge and attitude $28,37,38,52-54,56-58$.

\section{Age Range:}

All of the studies included adolescents between the ages of 15-17 years old. However, nine studies included adolescents $\leq 14$ years old as well as middle adolescents $\geq 15$ years old $8,22,37,38,50,51,54,56,58$. Sadoh et al. ${ }^{54}$ and Gargano et al.' $\mathrm{s}^{22}$ studies included the largest age ranges with students being between 9-17 years old and 11-18 years old respectively, with the same intervention being given to all students. Kwan et al. ${ }^{37}$ included students $12-17$ years old also providing the same intervention for all students.

Only two of the studies ${ }^{54,58}$ analysed differences in outcome measures in terms of age range. Sadoh et al. ${ }^{54}$, indicated that there were no statistically significant differences in the mean scores between different ages before or after the intervention though age-specific baseline scores are not presented. However, Ali et al's ${ }^{58}$ study found significantly improved knowledge in 16-year-old students compared to 13-14 years old students at baseline. Post-intervention, all students increased their knowledge significantly.

\section{Data Collection:}

Thirteen of the fifteen studies conducted a pre-intervention questionnaire to establish baseline knowledge of HPV and associated cancers in the control and intervention group. Davies et al. ${ }^{8}$ provided a baseline questionnaire to the control group only and Lloyd et al. ${ }^{56}$ did not include any baseline questionnaire.

Ten of the studies provided a post-intervention questionnaire directly after the intervention while seven studies captured information regarding attrition of knowledge at later time periods $3,8,28,38,51,53,58$ up to a maximum of 6 months $^{8,51,53,58}$. 


\section{Gender Inclusion}

Nine of the fifteen studies included females only while five included both genders $3,8,38,52,58$ in their target populations. Merzouk et al. ${ }^{50}$ did not state the gender of the population though the intervention assessment questions would imply that the population was female only.

\section{Development and Design of Interventions}

Significant variability was found in the design and content of the interventions in the studies. Psychological research has demonstrated that behaviours and behaviour change follow a predictable pattern and increasing evidence suggests that health-promotion interventions to affect behaviours are more effective when grounded in evidenced theory ${ }^{59}$. Glanz and Bishop's article ${ }^{59}$ summarises a number of behavioural science theories used for development and implementation of health promotion interventions including the Health Belief Model (HBM), The Theory of Reasoned Action (TRA) and Social Cognitive Theory $(\mathrm{SCT})^{59}$.

Five studies ${ }^{3,8,22,28,52}$ utilized concepts from the HBM to guide their teaching structure. Grandahl et al. ${ }^{3}$ and Gargano et al. ${ }^{22}$ also incorporated aspects of the TRA in the formation of their intervention. Gargano et al. ${ }^{22}$ also conducted a series of focus groups with middle- and high-school students, parents, and teachers to inform intervention structure and content. Davies et al. ${ }^{8}$, along with utilizing the HBM, also incorporated aspects of the Biopsychosocial Model and constructs of the Theory of Planned Behavior and SCT. This study additionally included a diverse range of stakeholder input in the creation of their programme. These 5 studies subsequently developed the most sophisticated and engaging interventions yielding statistically significant outcomes in terms of improved knowledge and attitude towards HPV vaccination. For example, Davies et al.' $\mathrm{s}^{8}$ intervention included an interactive lesson, take-home magazine, DVD with guide, app and website educational resources with relaxation methods to help increase the student comfort with the topic. Collectively, this study included 18 different teaching resources with guides to improve consistency in the intervention. Gargano et al. ${ }^{22}$ also utilized a combination of activities in their intervention including interactive games, projects, hands-on activities and powerful imagery in addition to utilizing colourful and animated PowerPoint slides. As with Davies et al' $^{8}{ }^{8}$ study, teaching guides were also created to improve consistency in the educational intervention.

Grandahl et al. ${ }^{3}$, Davies et al. ${ }^{8}$ and Gottvall et al. ${ }^{52}$, while covering the aforementioned topics, also included education around sexual behavior, condom use and various transmission routes of infection. Gottvall et al's $\mathrm{s}^{52}$ intervention even involved practical teaching about how to use condoms. These 3 studies, which are all considered of high quality, included both females and males. These 3 studies also yielded statistically significant outcomes in terms of future sexual behavioural intentions.

Other models or theories utilized through the studies included the Theory of Persuasion ${ }^{37}$ and a thematic analysis based on Leventhal's Common Sense Model of lay illness representations ${ }^{60}$.

However, eight of the studies $38,50,51,53-55,57,58$ did not provide any details of theoretical models that they used to guide them in the planning and development of their educational intervention. Their 
interventions were generally simplistic in nature with a brochure/pamphlet only ${ }^{55,58}$, DVD only ${ }^{50}$ or a didactic presentation with a brochure/pamphlet ${ }^{53,54,57}$ or without a brochure/pamphlet ${ }^{38}$.

\section{Intervention format/delivery}

The time required to deliver each educational intervention ranged from 10 minutes $^{57}$ to 120 minutes $^{22}$. In most cases, the intervention was delivered by a professional with a nursing, healthcare or medical background $3,28,37,38,51,52,54,57$. Only 3 studies included active interventions which were conducted by school health and social care teachers or science teachers ${ }^{8,22,50}$. One study involved an intervention conducted by a teacher with a nursing background ${ }^{28}$. See Table 1 for full details of each intervention.

Despite the variability in the intervention length and design, all studies (even those with short simple designs) demonstrated improved participant knowledge of HPV vaccination, HPV and it's associated cancers after any intervention.

\section{Discussion}

This literature review of 15 studies on interventions to improve HPV uptake, vaccination intentions, or attitudes among middle adolescents across the globe, demonstrates both the impact of interventions in this important demographic as well as potential novel directions for future work.

As previously established, only three of the fifteen studies explored the actual effect of the intervention on HPV vaccination uptake ${ }^{3,8,51}$. Combined findings from Davies et al. ${ }^{8}$ and Grandahl et al's. ${ }^{3}$ large high quality studies and Yoost et al's $\mathrm{s}^{51}$ smaller study, demonstrate the potential to increase HPV vaccination uptake rates in middle adolescent populations through school-based interventions, especially in countries where the initial vaccination uptake is quite low. Although a number of studies measured intention to be vaccinated $22,28,37,38,56,57$, previous studies have demonstrated inconsistencies between intention to vaccinate and actual vaccination ${ }^{61,62}$ making 'intention' an unreliable predictor of uptake. With only three studies exploring the actual impact of educational interventions in middle adolescent populations, there is a need for further research in to this area.

Perhaps the most important aspect of this topic is the issue of self-consent. Introducing gender and ageappropriate information to 15-17 year old students provides them with the opportunity to self-consent to HPV vaccinations without the need for consent from their parents in many countries including the UK, Canada, Sweden and parts of the US ${ }^{23,24,63,64}$. Unsurprisingly, the HPV vaccine can create ethical challenges for schools where there is some reticence about vaccinating without written parental consent ${ }^{23,24,63}$. This is an important opportunity for middle adolescents to make personal and private decisions about their future health and wellbeing, which may not necessarily align with their parents' viewpoint regarding this vaccine. It is, therefore, also important that students are provided with information regarding how they can access the HPV vaccination if they choose to have the vaccination at this time. 
A variety of interventions were used through the 15 studies, with Davies et al. ${ }^{8}$ and Gargano et al. ${ }^{22}$ including a vast array of stakeholder input in to the design of their interventions alongside sound supporting scientific theory. These two studies resulted in the most diverse and engaging interventions. Gargano et al. ${ }^{22}$, with stakeholder engagement, designed the same intervention for all students ranging in age from 11-18 years of age. However, they did not acknowledge this as being a limitation of their study. Davies et al.' $s^{8}$ intervention was designed for young adolescents at the time of initial vaccination rather than for middle adolescents. While a wide range of development and behaviour for each age is normal, certain attitudes, behaviours, and physical characteristics tend to occur at specific ages ${ }^{65.66}$. Adolescence is a time of constant transition where major developments related to sexuality takes place ${ }^{67}$ resulting in unique information needs at different ages in the adolescent spectrum. It is, therefore, paramount, that interventions are specifically designed to address the needs and interests of middle adolescents who have priorities that are different to their younger counterparts. Additionally, it is essential that this population play a key role in informing the creation of any proposed future intervention for this group.

\section{$\underline{\text { Intervention Benefits }}$}

The content of the interventions largely focused on cervical cancer with only five of the fifteen studies including both genders $3,8,38,52,58$ and no studies including males only. Even where both genders were included, the information tended to focus on cervical cancer with little discussion around oropharyngeal cancer, which has now become one of the leading HPV associated cancers globally with men having a 34 fold increase in risk compared to women ${ }^{68}$. Many adolescents who have not had vaginal intercourse, have engaged in sexual activity in the form of oral sex ${ }^{69-71}$ but are unaware that HPV can be transmitted via this route ${ }^{72}$. Only a small number of studies ${ }^{3,8,51,52}$ really encouraged the use of open dialogue around the important issues relating to sexual behavior and HPV risk. Education at this time point should discuss the risks of acquiring HPV infections through vaginal, oral and anal sex along with prevention strategies to avoid infection. Where both genders were included in the study, the depth of discussion seemed to broaden to include wider discussion around sexual behavior and HPV prevention. Researchers who included males may be more likely to be passionate about ensuring that the risks of oropharyngeal, penile and anal cancer are understood in both male and female adolescents.

In the eligible studies, the education intervention session was taught by a variety of professionals including teachers ${ }^{8,22,50}$, healthcare professionals ${ }^{3,28,37,51}$ and the research team, who primarily had a healthcare background ${ }^{38,52,54,57}$. However, a recent review by Pound et al. ${ }^{73}$, found that students often described their sexual education lessons with teachers as being clinical, with teachers often embarrassed to discuss issues like oral sex, and students equally reluctant to open up about private matters to their teachers. For this reason, the concept of peer education is an interesting one, though this was only explored in one isolated study ${ }^{54}$. Whilst a huge increase in understanding and knowledge was observed after this peer teaching intervention, the knowledge gain was significantly less than the standard education in this study. This may be due to the lack of training provided to students to teach their peers, as the format of the peer teaching can have a large effect on the impact of the teaching ${ }^{74}$. This format may well be worth exploring in the future as students reported feeling 'a sense of affinity' with their peers, encouraging them to believe information delivered by peer educators ${ }^{54}$. Previous findings have also indicated that peer training can increase knowledge and enhance preventive behaviors regarding sexually transmitted diseases (STDs) ${ }^{75,76}$. Further research directed at exploring the value of peer-teaching for HPV education in teenagers would be beneficial in the future. 
One of the common concerns from schools is the time and resources required to implement an educational strategy of this nature ${ }^{50}$. However, this review demonstrates than even a short educational intervention with few resources can have a significant impact on knowledge gained and increase positive attitudes to safe sex and HPV vaccination. This intervention is even more important in countries where there is a cost associated with the HPV vaccine as these countries typically have lower vaccination rates $^{9}$.

\section{Intervention Frequency}

A number of studies measured their outcomes at various time-points up to 6 months postintervention $3,8,28,38,51,53,58$. Their findings suggest that altered intentions and retention of information from the intervention, remains up to approximately 6 months post-intervention. After this time, small reductions in retention were observed, though they were still much higher than at baseline ${ }^{8,51,58}$. This may suggest the need for short annual refresher interventions, specifically designed for middle adolescents, to obtain optimal impact, supporting the findings of previous studies ${ }^{38,77}$. Studies need to follow-up students for longer periods post-intervention in order to verify this theory. Longer follow-up is also needed to understand whether intention translates in to real-lived behaviors including an increase in the uptake of HPV vaccination, cervical screening and increased condom use; all ways to reduce the incidence of HPV associated cancers ${ }^{78,79}$.

\section{Conclusion}

This literature review provides evidence that implementation of educational interventions improves HPV uptake, vaccination intentions, and attitudes among middle adolescents globally. Currently, there is no evidence that any form of standard HPV education is being provided by schools to middle adolescents who are most likely to understand the relevance of this information and potentially adapt their future health and sexual practice behaviours as a result of this education. HPV vaccinations should be offered in conjunction with both an initial educational intervention and annual follow-up interventions for middle adolescents, to maximize vaccination uptake. These interventions, with information regarding associated cancers, should be a mandated school-based intervention, adapted to this specific age group and mixed genders. Interventions need to be sensitively constructed with input from students, teachers and the community outside of the school environment ${ }^{19}$. Some standardization of outcome measures used to capture information related to knowledge, attitude and intention to vaccinate is needed as there is currently a wide variety of tools used in the published research to assess these parameters. A theoretical foundation is becoming almost mandatory in the development of health education, as we are primarily interested in predicting and understanding patterns of behaviours in specific populations ${ }^{80}$. This review supports the incorporation of behavioural science theories in the development of multimodal HPV related education for this population, as this results in a robust and engaging practical approach to education delivery $8,22,52$.

Conflict of Interest: The authors declare that they have no conflict of interest and received no financial support to complete this research. 


\section{$\underline{\text { References }}$}

1. World Health Organisation. Human papillomavirus (HPV) and cervical cancer. [Online] Available from: https://www.who.int/en/news-room/fact-sheets/detail/human-papillomavirus-(hpv)-and-cervicalcancer [Accessed 20 March 2020].

2. Garland SM, Kjaer SK, Muñoz N, Block SL, Brown DR, DiNubile MJ, Lindsay BR, Kuter BJ, Perez G, Dominiak-Felden G, Saah AJ. Impact and effectiveness of the quadrivalent human papillomavirus vaccine: a systematic review of 10 years of real-world experience. Reviews of Infectious Diseases. 2016 May 26;63(4):519-27.

3. Grandahl M, Rosenblad A, Stenhammar C, Tydén T, Westerling R, Larsson M, Oscarsson M, Andrae B, Dalianis T, Nevéus T. School-based intervention for the prevention of HPV among adolescents: a cluster randomised controlled study. BMJ open. 2016 Jan 1;6(1):e009875.

4. World Health Organisation. Human Papillomavirus (HPV) Vaccine Background Paper. [Online] Available from: https://www.who.int/immunization/documents/HPVBGpaper final 0304 2009.pdf [Accessed 13 March 2020].

5. Gostin LO. Mandatory HPV vaccination and political debate. Jama. 2011 Oct 19;306(15):1699-700.

6. Centres for disease control and prevention. Genital HPV Infection - Fact Sheet. [Online]. Available from: https://www.cdc.gov/std/hpv/stdfact-hpv.htm [Accessed 13 March 2020].

7. Diaz ML. Prevention of cervical, vaginal, and vulval cancers: role of the quadrivalent human papillomavirus $(6,11,16,18)$ recombinant vaccine. International journal of women's health. 2009;1:119.

8. Davies C, Skinner SR, Stoney T, Marshall HS, Collins J, Jones J, Hutton H, Parrella A, Cooper S, McGeechan K, Zimet G. 'Is it like one of those infectious kind of things?'The importance of educating young people about HPV and HPV vaccination at school. Sex Education. 2017 May 4;17(3):256-75.

9. Loke AY, Kwan ML, Wong YT, Wong AK. The Uptake of Human Papillomavirus Vaccination and Its Associated Factors Among Adolescents: A Systematic Review. Journal of primary care \& community health. 2017 Oct;8(4):349-62.

10. Chaturvedi AK, Graubard BI, Broutian T, Pickard RK, Tong ZY, Xiao W, Kahle L, Gillison ML. Effect of prophylactic human papillomavirus (HPV) vaccination on oral HPV infections among young adults in the United States. Journal of Clinical Oncology. 2018 Jan 20;36(3):262.

11. Fu LY, Bonhomme LA, Cooper SC, Joseph JG, Zimet GD. Educational interventions to increase HPV vaccination acceptance: a systematic review. Vaccine. 2014 Apr 7;32(17):1901-20.

12. Beshers SC, Murphy JM, Fix BV, Mahoney MC. Sex differences among college students in awareness of the human papillomavirus vaccine and vaccine options. Journal of American College Health. 2015 Feb 17;63(2):144-7. 
13. Baandrup L, Blomberg M, Dehlendorff C, Sand C, Andersen KK, Kjaer SK. Significant decrease in the incidence of genital warts in young Danish women after implementation of a national human papillomavirus vaccination program. Sexually transmitted diseases. 2013 Feb 1;40(2):130-5.

14. Schurink TM, de Melker HE. HPV vaccination: Background information for the Dutch Health Council; 2017 [online] https://www.rivm.nl/bibliotheek/rapporten/2017-0020.pdf [Accessed 17 March 2020]

15. Thamsborg LH, Andersen B, Larsen LG, Christensen J, Johansen T, Hariri J, Christiansen S, Rygaard C, Lynge E. Danish method study on cervical screening in women offered HPV vaccination as girls (Trial23): a study protocol. BMJ open. 2018 May 1;8(5):e020294.

16. World Health Organisation; Regional Office for Europe. Collaboration among immunization programmes aims to bring Europe closer to stopping HPV. [Online] Available from: http://www.euro.who.int/en/health-topics/disease-prevention/vaccines-andimmunization/news/news/2017/07/collaboration-among-immunization-programmes-aims-to-bringeurope-closer-to-stopping-hpv [Accessed 8 April 2020]

17. Skinner SR, Davies C, Cooper S, Stoney T, Marshall H, Jones J, Collins J, Hutton H, Parrella A, Zimet G, Regan DG. HPV. edu study protocol: a cluster randomised controlled evaluation of education, decisional support and logistical strategies in school-based human papillomavirus (HPV) vaccination of adolescents. BMC public health. 2015 Dec;15(1):896.

18. Brawner BM, Baker JL, Voytek CD, Leader A, Cashman RR, Silverman R, Peter N, Buchner BJ, Barnes CA, Jemmott LS, Frank I. The development of a culturally relevant, theoretically driven HPV prevention intervention for urban adolescent females and their parents/guardians. Health Promotion Practice. 2013 Jul;14(4):624-36.

19. Fonner VA, Armstrong KS, Kennedy CE, O'Reilly KR, Sweat MD. School based sex education and HIV prevention in low-and middle-income countries: a systematic review and meta-analysis. PloS one. 2014 Mar 4;9(3):e89692.

20. Paskett ED, Krok-Schoen JL, Pennell ML, Tatum CM, Reiter PL, Peng J, Bernardo BM, Weier RC, Richardson MS, Katz ML. Results of a Multilevel Intervention Trial to Increase Human Papillomavirus (HPV) Vaccine Uptake among Adolescent Girls. Cancer Epidemiol Biomarkers Prev. 2016 Apr;25:4.

21. Pot M, Paulussen TG, Ruiter RA, Eekhout I, De Melker HE, Spoelstra ME, Van Keulen HM. Effectiveness of a web-based tailored intervention with virtual assistants promoting the acceptability of HPV vaccination among mothers of invited girls: randomized controlled trial. Journal of medical Internet research. 2017;19(9):e312.

22. Gargano LM, Herbert NL, Painter JE, Sales JM, Vogt TM, Morfaw C, Jones LM, Murray D, DiClemente RJ, Hughes JM. Development, theoretical framework, and evaluation of a parent and teacher-delivered intervention on adolescent vaccination. Health promotion practice. 2014 Jul;15(4):556-67.

23. Audrey S, Ferrer HB, Ferrie J, Evans K, Bell M, Yates J, Roderick M, MacLeod J, Hickman M. Impact and acceptability of self-consent procedures for the school-based human papillomavirus vaccine: a mixed-methods study protocol. BMJ open. 2018 Mar 1;8(3):e021321. 
24. Gottvall M. Introduction of School-Based HPV Vaccination in Sweden: Knowledge and Attitudes among Youth, Parents, and Staff (Doctoral dissertation, Acta Universitatis Upsaliensis); 2014

25. Porter RM, Amin AB, Bednarczyk RA, Omer SB. Cancer-salient messaging for Human Papillomavirus vaccine uptake: A randomized controlled trial. Vaccine. 2018 Apr 25;36(18):2494-500

26. Smith LM, Kaufman JS, Strumpf EC, Lévesque LE. Effect of human papillomavirus (HPV) vaccination on clinical indicators of sexual behaviour among adolescent girls: the Ontario Grade 8 HPV Vaccine Cohort Study. Canadian Medical Association Journal. 2014 Jan 1:cmaj-140900.

27. Mattebo M, Grün N, Rosenblad A, et al. Sexual experiences in relation to HPV vaccination status in female high school students in Sweden. Eur J Contracept Reprod Health Care 2014;19:86-92.

28. Lai CY, Wu WW, Tsai SY, Cheng SF, Lin KC, Liang SY. The effectiveness of a Facebook-assisted teaching method on knowledge and attitudes about cervical cancer prevention and HPV vaccination intention among female adolescent students in Taiwan. Health Education \& Behavior. 2015 Jun;42(3):352-60.

29. Kessels SJ, Marshall HS, Watson M, Braunack-Mayer AJ, Reuzel R, Tooher RL. Factors associated with HPV vaccine uptake in teenage girls: a systematic review. Vaccine. 2012 May 21;30(24):3546-56.

30. Ramiro L, Windlin B, Reis M, Gabhainn SN, Jovic S, Matos MG, Magnusson J, Godeau E. Gendered trends in early and very early sex and condom use in 20 European countries from 2002 to 2010 . The European Journal of Public Health. 2015 Mar 20;25(suppl_2):65-8.

31. Virginia department of health. SSuN Special Focus Report; Age of First Sexual Intercourse . [Online]. Available from: http://www.vdh.virginia.gov/content/uploads/sites/10/2016/01/SSuN-FactSheet-Age1stSex-04-10-13.pdf [Accessed 8 April 2020].

32. The Family Planning Association . Sexual Behaviour Factsheet. [Online]. Available from: https://www.fpa.org.uk/factsheets/sexual-behaviour [Accessed 8 April 2020].

33. Yaya S, Bishwajit G. Age at first sexual intercourse and multiple sexual partnerships among women in Nigeria: a cross-sectional analysis. Frontiers in Medicine. 2018;5:171.

34. Marino JL, Skinner SR, Doherty DA, Rosenthal SL, Robbins SC, Cannon J, Hickey M. Age at menarche and age at first sexual intercourse: a prospective cohort study. Pediatrics. 2013 Nov 1:peds-2012.

35. The French Institute for Demographic Studies. Age at first sexual intercourse in France. [Online]. Available from: https://www.ined.fr/en/everything about population/demographicfacts-sheets/focus-on/age first sexual intercourse/ [Accessed 8 April 2020].

36. Tullock T., Kaufman M. Adolescent Sexuality. Pediatrics in Review. January 2013, Volume 34 / Issue1

37. Kwan TT, Tam KF, Lee PW, Chan KK, Ngan HY. The effect of school-based cervical cancer education on perceptions towards human papillomavirus vaccination among Hong Kong Chinese adolescent girls. Patient education and counseling. $2011 \mathrm{Jul}$ 1;84(1):118-22. 
38. Marek E, Dergez T, Rebek-Nagy G, Szilard I, Kiss I, Ember I, Gocze P, D'Cruz G. Effect of an educational intervention on Hungarian adolescents' awareness, beliefs and attitudes on the prevention of cervical cancer. Vaccine. 2012 Nov 6;30(48):6824-32.

39. Schülein S, Taylor KJ, König J, Claus M, Blettner M, Klug SJ. Factors influencing uptake of HPV vaccination among girls in Germany. BMC public health. 2016 Dec;16(1):995.

40. Elfström KM, Dillner J, Arnheim-Dahlström L. Organization and quality of HPV vaccination programs in Europe. Vaccine. 2015 Mar 30;33(14):1673-81.

41. Centres for Disease Control and Prevention. Sexually Transmitted Diseases Surveillance 2017. [Online] Available from: https://www.cdc.gov/std/stats17/2017-STD-Surveillance-Report CDCclearance-9.10.18.pdf [Accessed 28 March 2020].

42. Bennett AT, Patel DA, Carlos RC, Zochowski MK, Pennewell SM, Chi AM, Dalton VK. Human papillomavirus vaccine uptake after a tailored, online educational intervention for female university students: a randomized controlled trial. Journal of Women's Health. 2015 Nov 1;24(11):950-7.

43. Bernardo WM. PRISMA statement and PROSPERO. International braz j urol. 2017 Jun;43(3):383-4.

44. B.C Open Education. Chapter 7: Quasi-experimental Research. [Online]. Available from: https://opentextbc.ca/researchmethods/chapter/quasi-experimental-research/ [Accessed 1 April 2020]. 45. Jun-Young Choi, \& So-Young Choi. (2013). Effects of human papilloma virus on related education for female high school students. Asian Oncology Nursing, 13(3), 128-135.

46. Castellanos M., Odaimi T., Demissie S., Lee A., \& Farberov, M. (2018). A new peer-to-peer educational model to in-crease knowledge and acceptability of HPV vaccination. , 62. (2 Supplement 1) pp. S105-S106.

47. National Collaborating Centre for Measures and Tools. Quality assessment tool for quantitative studies. [Online]. Available from: https://www.nccmt.ca/knowledge-repositories/search/14 [Accessed 2 April 2020].

48. Armijo-Olivo S, Stiles CR, Hagen NA, Biondo PD, Cummings GG. Assessment of study quality for systematic reviews: a comparison of the Cochrane Collaboration Risk of Bias Tool and the Effective Public Health Practice Project Quality Assessment Tool: methodological research. Journal of evaluation in clinical practice. $2012 \mathrm{Feb}$;18(1):12-8

49. Sun WH, Miu HY, Wong CK, Tucker JD, Wong WC. Assessing participation and effectiveness of the peer-led approach in youth sexual health education: systematic review and meta-analysis in more developed countries. The Journal of Sex Research. 2018 Jan 2;55(1):31-44.

50. Merzouk MD, Courtney P, Garrett-Albaugh S, Janoo J, Hobbs G, Vernon M. Knowledge of HPV in West Virginia high school health students and the effects of an educational tool. Journal of pediatric and adolescent gynecology. 2011 Oct 1;24(5):278-81. 
51. Yoost JL, Starcher RW, King-Mallory RA, Hussain N, Hensley CA, Gress TW. The use of telehealth to teach reproductive health to female rural high school students. Journal of pediatric and adolescent gynecology. 2017 Apr 1;30(2):193-8.

52. Gottvall M, Tydén T, Höglund AT, Larsson M. Knowledge of human papillomavirus among high school students can be increased by an educational intervention. International journal of STD \& AIDS. 2010 Aug;21(8):558-62.

53. Ifediora CO, Azuike EC. Targeting cervical cancer campaigns on teenage high schoolers in resourcelimited economies: lessons from an intervention study of Nigerian senior secondary school girls. Family practice. 2018 Dec 12

54. Sadoh AE, Okonkwobo C, Nwaneri DU, Ogboghodo BC, Eregiea C, Oviawe O, Famuyiwa O. Effect of Peer Education on Knowledge of Human Papilloma Virus and Cervical Cancer among Female Adolescent Students in Benin City, Nigeria. Annals of global health. 2018 Apr 30;84(1).

55. Steckelberg A, Albrecht M, Kezle A, Kasper J, Mühlhauser I. Impact of numerical information on risk knowledge regarding human papillomavirus (HPV) vaccination among schoolgirls: a randomised controlled trial. GMS German Medical Science. 2013;11

56. Lloyd GP, Marlow LA, Waller J, Miles A, Wardle J. An experimental investigation of the emotional and motivational impact of HPV information in adolescents. Journal of Adolescent Health. 2009 Nov 1;45(5):532-4.

57. Lim SW, Boo AY, Tan WC, Png ES, Lee HK, Chang ZY, Wee SX, Balakrishnan B, Choong KS, Phoon IK. A cohort survey of the effect of an educational intervention on human papillomavirus vaccine-related knowledge and attitudes among pre-university female students in Singapore. Proceedings of Singapore Healthcare. 2017 Mar;26(1):5-10.

58. Ali A.N., Jie J.S., Prajapati S.K., Iqbal M.Z., Ahmed N.Z., \& Alshammari, T. M. (2018). A longitudinal KAP study on HPV immunised adolescents' in malaysia. Journal of Natural Remedies, 18(3), 86-99.

59. Glanz K, Bishop DB. The role of behavioral science theory in development and implementation of public health interventions. Annual review of public health. 2010 Apr 21;31:399-418.

60. Hale ED, Treharne GJ, Kitas GD. The Common-Sense Model of self-regulation of health and illness: how can we use it to understand and respond to our patients' needs?. Rheumatology. 2007 Jun 1;46(6):904-6.

61. Armitage CJ and Conner M (1999) The theory of planned behaviour: Assessment of predictive validity and 'perceived control'. British Journal of Social Psychology 38(1): 35-54

62. Wegwarth O, Kurzenhäuser-Carstens S, Gigerenzer G. Overcoming the knowledge-behavior gap: the effect of evidence-based HPV vaccination leaflets on understanding, intention, and actual vaccination decision. Vaccine. 2014 Mar 10;32(12):1388-93.

63. Wood F, Morris L, Davies M, Elwyn G. What constitutes consent when parents and daughters have different views about having the HPV vaccine: qualitative interviews with stakeholders. Journal of medical ethics. 2011 Aug 1;37(8):466-71. 
64. NHS. Vaccinations. [Online]. Available from: https://www.nhs.uk/conditions/vaccinations/hpvhuman-papillomavirus-vaccine/ [Accessed 9 April 2020].

65. American Academy of Paediatrics . Adolescent Sexual Health. [Online]. Available from: https://www.aap.org/en-us/advocacy-and-policy/aap-health-initiatives/adolescent-sexualhealth/Pages/Stages-of-Adolescent-Development.aspx [Accessed 6 April 2020].

66. Wayne State University Physician Group. Normal Development: Late Adolsecence (18-20 years old). [On-line]. Available from:

http://www.wsupgdocs.org/familymedicine/WayneStateContentPage.aspx?nd=1602 [Accessed 9 April 2020]

67. Kar SK, Choudhury A, Singh AP. Understanding normal development of adolescent sexuality: A bumpy ride. Journal of human reproductive sciences. $2015 \mathrm{Apr} ; 8(2): 70$

68. You EL, Henry M, Zeitouni AG. Human papillomavirus-associated oropharyngeal cancer: review of current evidence and management. Current Oncology. 2019 Apr;26(2):119.

69. Higgins JA, Trussell J, Moore NB, Davidson JK. Young adult sexual health: current and prior sexual behaviours among non-Hispanic white US college students. Sexual health. 2010 Mar 9;7(1):35-43.

70. Chow EP, Wigan R, McNulty A, Bell C, Johnson M, Marshall L, Regan DG, Owen L, Brotherton JM, Bradshaw CS, Fairley CK. Early sexual experiences of teenage heterosexual males in Australia: a crosssectional survey. BMJ open. 2017 Oct 1;7(10):e016779.

71. Holway GV. Vaginal and oral sex initiation timing: A focus on gender and race/ethnicity. International Journal of Sexual Health. 2015 Jul 3;27(3):351-67.

72. Stock ML, Peterson LM, Houlihan AE, Walsh LA. Influence of oral sex and oral cancer information on young adults' oral sexual-risk cognitions and likelihood of HPV vaccination. Journal of sex research. 2013 Jan 1;50(1):95-102

73. Pound P, Langford R, Campbell R. What do young people think about their school-based sex and relationship education? A qualitative synthesis of young people's views and experiences. BMJ open. 2016 Sep 1;6(9):e011329.

74. Rees EL, Davies B, Eastwood M. Developing students' teaching through peer observation and feedback. Perspectives on medical education. 2015 Oct 1;4(5):268-71

75. van der Maas F, Otte WM. Evaluation of HIV/AIDS secondary school peer education in rural Nigeria. Health education research. 2008 Nov 5;24(4):547-57.

76. Hatami M, Kazemi A, Mehrabi T. Effect of peer education in school on sexual health knowledge and attitude in girl adolescents. Journal of education and health promotion. 2015;4.

77. Scott-Sheldon LA, Fielder RL, Carey MP. Sexual risk reduction interventions for patients attending sexually transmitted disease clinics in the United States: a meta-analytic review, 1986 to early 2009. Annals of Behavioral Medicine. 2010 Jul 23;40(2):191-204. 
78. Lowy DR, Schiller JT. Reducing HPV-associated cancer globally. Cancer prevention research. 2012 Jan 1;5(1):18-23.

79. Pierce Campbell CM, Lin HY, Fulp W, Papenfuss MR, Salmerón JJ, Quiterio MM, Lazcano-Ponce E, Villa LL, Giuliano AR. Consistent condom use reduces the genital human papillomavirus burden among high-risk men: the HPV infection in men study. The Journal of infectious diseases. 2013 Aug 1;208(3):373-84

80. Sharma M. Theoretical foundations of health education and health promotion. Jones \& Bartlett Publishers; 2016 Mar 1 


\begin{tabular}{|c|c|c|c|c|c|c|c|}
\hline $\begin{array}{l}\text { Bibliographic } \\
\text { Information }\end{array}$ & Study design & Aims of study & $\begin{array}{l}\text { Study } \\
\text { Population }\end{array}$ & $\begin{array}{l}\text { Theory of } \\
\text { intervention }\end{array}$ & $\begin{array}{l}\text { Intervention } \\
\text { Design }\end{array}$ & $\begin{array}{l}\text { Data } \\
\text { Collection } \\
\text { Timeline }\end{array}$ & $\begin{array}{l}\text { Statistically Significant } \\
\text { Measured Outcomes }\end{array}$ \\
\hline $\begin{array}{l}\text { Ali et al. } \\
2018 \\
\text { (Malaysia) }\end{array}$ & $\begin{array}{l}\text { Quasi- } \\
\text { experimental } \\
\text { Pre-test/Post- } \\
\text { test with } 1 \\
\text { group only }\end{array}$ & $\begin{array}{l}\text { 1. Assess } \\
\text { Knowledge, } \\
\text { Attitude and } \\
\text { Perception (KAP) } \\
\text { level changes } \\
\text { among HPV } \\
\text { vaccinated } \\
\text { secondary school } \\
\text { adolescents pre } \\
\text { and post an } \\
\text { educational } \\
\text { intervention. } \\
\text { 2. Estimate the } \\
\text { impact of the } \\
\text { educational } \\
\text { intervention on } \\
\text { KAP over time. }\end{array}$ & $\begin{array}{l}\text { Age: } 13,14 \text { and } \\
16 \\
\text { Gender: Males } \\
\text { and females } \\
\text { included } \\
\text { Numbers: } \\
2,928 \text { appear } \\
\text { to have } \\
\text { completed the } \\
3 \\
\text { questionnaires } \\
\\
\text { (HPV } \\
\text { vaccination } \\
\text { secondary } \\
\text { school } \\
\text { students who } \\
\text { received at } \\
\text { least the } 1^{\text {st }} \\
\text { vaccination } \\
\text { dose. ) }\end{array}$ & $\begin{array}{l}\text { Not discussed. } \\
\text { (Health Belief Model } \\
\text { mentioned but no } \\
\text { indication that it was } \\
\text { utilized in the design } \\
\text { of the intervention.) }\end{array}$ & $\begin{array}{l}\text { Intervention: } \\
\text { Educational } \\
\text { pamphlet } \\
\text { containing } \\
\text { information } \\
\text { related to HPV } \\
\text { infection, } \\
\text { cervical cancer, } \\
\text { its screening and } \\
\text { HPV vaccination. } \\
\text { There is no } \\
\text { indication of } \\
\text { who provided } \\
\text { the class with } \\
\text { the pamphlet } \\
\text { and no evidence } \\
\text { to suggest Q\&A } \\
\text { opportunity. } \\
\text { The pamphlet } \\
\text { could have been } \\
\text { read anywhere } \\
\text { and at any time. } \\
\text { There is no way } \\
\text { of establishing } \\
\text { whether all } \\
\text { students read } \\
\text { the pamphlet . }\end{array}$ & $\begin{array}{l}\text { A baseline } \\
\text { questionnaire } \\
\text { was } \\
\text { completed } \\
\text { prior to the } \\
\text { intervention. } \\
\text { A second } \\
\text { questionnaire } \\
\text { was } \\
\text { completed } 2 \\
\text { weeks after } \\
\text { intervention. } \\
\text { A third } \\
\text { questionnaire } \\
\text { was } \\
\text { completed } \\
\text { between 3-6 } \\
\text { months post- } \\
\text { intervention. }\end{array}$ & $\begin{array}{l}\text { 1. Knowledge, } \\
\text { attitude and } \\
\text { perception all } \\
\text { improved significantly } \\
2 \text { weeks after the } \\
\text { intervention. } \\
\text { 2. } 3-6 \text { months post- } \\
\text { intervention, KAP } \\
\text { scores had fallen but } \\
\text { were still significantly } \\
\text { higher than at } \\
\text { baseline. }\end{array}$ \\
\hline
\end{tabular}




\begin{tabular}{|c|c|c|c|c|c|c|c|}
\hline $\begin{array}{l}\text { Sadoh et al. } \\
2018 \\
\text { (Nigeria) }\end{array}$ & $\begin{array}{l}\text { Quasi- } \\
\text { experimental } \\
\text { Pre-test/Post- } \\
\text { test with } 2 \\
\text { groups }\end{array}$ & $\begin{array}{l}\text { 1. To assess the } \\
\text { knowledge of } \\
\text { female secondary } \\
\text { school students } \\
\text { about cervical } \\
\text { cancer and HPV } \\
\text { risk } \\
\text { 2. To determine if } \\
\text { their knowledge } \\
\text { could be } \\
\text { improved using } \\
\text { peer-to-peer } \\
\text { transfer of } \\
\text { knowledge. }\end{array}$ & $\begin{array}{l}\text { Age: } 9-17 \\
\text { years old } \\
\text { Gender: } \\
\text { Female only } \\
\text { Numbers: } \\
1337 \text { students } \\
\text { (from } 4 \\
\text { schools) } \\
\text { completed } \\
\text { baseline } \\
\text { questionnaire. } \\
\text { Following peer } \\
\text { training, } 1201 \\
\text { students } \\
\text { completed } \\
\text { post } \\
\text { intervention } \\
\text { questionnaire. }\end{array}$ & Not discussed & $\begin{array}{l}\text { Arm } 1 \\
\text { (Intervention 1; } \\
\text { seminar cohort): } \\
124 \text { students } \\
\text { participated in a } \\
\text { training seminar } \\
\text { involving a } \\
\text { lecture with a } \\
\text { brochure. } \\
\text { (Length of } \\
\text { seminar not } \\
\text { specified) } \\
\text { Arm 2: } \\
\text { (Intervention 2; } \\
\text { school cohort): } \\
\text { 1,337 students } \\
\text { participated in } \\
\text { Peer-teaching } \\
\text { using a brochure } \\
\text { as the basis of } \\
\text { discussion } \\
\text { (length of } \\
\text { discussion or } \\
\text { Q\&A } \\
\text { opportunities } \\
\text { not discussed) }\end{array}$ & $\begin{array}{l}\text { A baseline } \\
\text { questionnaire } \\
\text { was } \\
\text { completed by } \\
\text { all students } \\
\text { prior to } \\
\text { intervention } 1 \\
\text { or } \\
\text { intervention } 2 . \\
\text { A second post- } \\
\text { intervention } \\
\text { questionnaire } \\
\text { was } \\
\text { completed by } \\
\text { the seminar } \\
\text { cohort } \\
\text { immediately } \\
\text { after the } \\
\text { training while } \\
\text { for those in } \\
\text { the school } \\
\text { cohort, the } \\
\text { questionnaire } \\
\text { was collected } \\
\text { within } 3-5 \\
\text { days after } \\
\text { peer training. }\end{array}$ & $\begin{array}{l}\text { 1. Low awareness of } \\
\text { cervical cancer prior to } \\
\text { any intervention } \\
\text { ( 14.5\% had ever } \\
\text { heard of cervical } \\
\text { cancer) } \\
\text { 2. There was no } \\
\text { difference in the mean } \\
\text { knowledge score } \\
\text { between different } \\
\text { ages at baseline. } \\
\text { 3. Sizable increase in } \\
\text { understanding the link } \\
\text { between sexual } \\
\text { practices and HPV to } \\
\text { cervical cancer after } \\
\text { the intervention ( } p< \\
0.0001 \text { ). } \\
\text { 4. The mean } \\
\text { knowledge score for } \\
\text { the seminar cohort } \\
\text { post-training was } \\
\text { higher than that of the } \\
\text { school cohort though } \\
\text { both were }>80 \% \text { ( } p< \\
0.0001 \text { ). } \\
5 \text {. There was no } \\
\text { statistically significant } \\
\text { difference in the mean } \\
\text { scores between }\end{array}$ \\
\hline
\end{tabular}




\begin{tabular}{|c|c|c|c|c|c|c|c|}
\hline & & & & & & & $\begin{array}{l}\text { classes }(p=0.68) \text { and } \\
\text { between ages }(p= \\
0.27) \text { in seminar } \\
\text { cohort following } \\
\text { training. Following } \\
\text { peer training there } \\
\text { was no significant } \\
\text { difference in the mean } \\
\text { scores between } \\
\text { classes ( } p=0.26 \text { ) and } \\
\text { between different } \\
\text { ages }(p=0.60) \text { in the } \\
\text { school cohort. }\end{array}$ \\
\hline $\begin{array}{l}\text { Ifediora et } \\
\text { al. } 2018 \\
\text { (Nigeria) }\end{array}$ & $\begin{array}{l}\text { Quasi- } \\
\text { experimental } \\
\text { 2-armed study }\end{array}$ & $\begin{array}{l}\text { 1) To assess the } \\
\text { effect of an } \\
\text { intervention on } \\
\text { knowledge } \\
\text { regarding Pap } \\
\text { Smears, HPV } \\
\text { vaccines and } \\
\text { associated risk } \\
\text { factors } \\
\text { 2) To assess the } \\
\text { level of } \\
\text { engagement of } \\
\text { students in the } \\
\text { two intervention } \\
\text { options. }\end{array}$ & $\begin{array}{l}\text { Age: } 15-19 \\
\text { years (>90\%) } \\
\text { Gender: } \\
\text { Females only } \\
\text { Numbers: } \\
317(73.4 \%) \\
\text { and } 301 \\
\text { (69.7\%) valid } \\
\text { responses } \\
\text { were received } \\
\text { from the pre- } \\
\text { intervention } \\
\text { and post- } \\
\text { intervention } \\
\text { surveys from } \\
24 \text { schools. }\end{array}$ & Not discussed & $\begin{array}{l}\text { Arm } 1 \\
\text { (Intervention): } \\
\text { Voluntary } \\
\text { attendance at } \\
\text { 45-minute } \\
\text { PowerPoint- } \\
\text { assisted lecture. } \\
\text { Unclear who } \\
\text { delivered the } \\
\text { presentation or } \\
\text { whether Q\&A } \\
\text { opportunity. } \\
\text { All participants } \\
\text { received a } \\
\text { brochure with } \\
\text { the same } \\
\text { content as the } \\
\text { powerpoint. }\end{array}$ & $\begin{array}{l}\text { A baseline } \\
\text { questionnaire } \\
\text { was } \\
\text { completed by } \\
\text { both groups } \\
\text { prior to the } \\
\text { intervention. } \\
\text { A second post- } \\
\text { intervention } \\
\text { questionnaire } \\
\text { was } \\
\text { completed } 6 \\
\text { months after } \\
\text { the } \\
\text { intervention. }\end{array}$ & $\begin{array}{l}\text { 1. Significant } \\
\text { improvements in } \\
\text { knowledge across all } \\
\text { parameters (Pap } \\
\text { Smears, HPV Vaccines } \\
\text { and Risk Factors) } \\
\text { except on 'early } \\
\text { symptoms' in } \\
\text { intervention group. } \\
\\
\text { 2. Of the } 301 \text { post- } \\
\text { intervention } \\
\text { respondents, } 133 \\
\text { (44.2\%) attended the } \\
\text { symposium, while a } \\
\text { total of } 189 \text { (62.8\%) } \\
\text { read the handouts } \\
\text { (including some who }\end{array}$ \\
\hline
\end{tabular}




\begin{tabular}{|c|c|c|c|c|c|c|c|}
\hline & & & & & $\begin{array}{l}\text { Arm } 2 \text { (control): } \\
\text { No intervention }\end{array}$ & & $\begin{array}{l}\text { did not attend the } \\
\text { symposium). }\end{array}$ \\
\hline $\begin{array}{l}\text { Davies et al. } \\
2017 \\
\text { (Australia) }\end{array}$ & $\begin{array}{l}\text { 2-armed } \\
\text { Cluster RCT }\end{array}$ & $\begin{array}{l}\text { 1. To improve } \\
\text { student } \\
\text { knowledge about } \\
\text { HPV vaccination } \\
\text { 2. To improve } \\
\text { psycho-social } \\
\text { outcomes } \\
\text { including } \\
\text { attitudes to HPV. } \\
\text { 3. To improve } \\
\text { HPV vaccination } \\
\text { uptake. }\end{array}$ & $\begin{array}{l}\text { Age: } 13-15 \\
\text { Gender: Males } \\
\text { and Females } \\
\text { Numbers: } 40 \\
\text { schools with } \\
6,965 \text { students } \\
\text { recruited. }\end{array}$ & $\begin{array}{l}\text {-Biopsychosocial } \\
\text { model } \\
\text {-Health Belief model } \\
\text { (HBM) } \\
\text {-The Theory of } \\
\text { Planned Behaviour } \\
\text { and Social Cognitive } \\
\text { Theory. }\end{array}$ & $\begin{array}{l}\text { Arm } 1 \\
\text { (intervention): } \\
\text { Delivered by } \\
\text { mainly Health } \\
\text { and Social } \\
\text { teachers with } \\
\text { small groups } \\
\text { structure. } \\
\text { Average } 60 \\
\text { minutes though } \\
\text { range of } \\
\text { resources used } \\
\text { and time taken } \\
\text { including } \\
\text { activities, } \\
\text { magazines, DVD } \\
\text { and numerous } \\
\text { other options. } \\
\text { Arm } 2 \text { (control): } \\
\text { No education. }\end{array}$ & $\begin{array}{l}\text { A baseline } \\
\text { questionnaire } \\
\text { was } \\
\text { completed by } \\
\text { the control } \\
\text { group only but } \\
\text { not the } \\
\text { intervention } \\
\text { group. } \\
\text { A second } \\
\text { questionnaire } \\
\text { was } \\
\text { completed by } \\
\text { both groups } \\
6 \text { months } \\
\text { post- } \\
\text { intervention. } \\
\text { Semi- } \\
\text { structured } \\
\text { focus groups } \\
\text { and interviews } \\
\text { were also } \\
\text { conducted } \\
\text { with both } \\
\text { groups. }\end{array}$ & $\begin{array}{l}\text { 1. Statistically } \\
\text { significant difference } \\
\text { between groups with } \\
\text { increased HPV and } \\
\text { vaccination knowledge } \\
\text { in intervention group. } \\
\text { 2. Improved sexual } \\
\text { intentions in } \\
\text { intervention group. } \\
\text { 3. No change in HPV } \\
\text { vaccination uptake. } \\
\text { 4. While falling } \\
\text { slightly, knowledge } \\
\text { remained high in the } \\
\text { intervention group } 6 \\
\text { months post- } \\
\text { intervention. }\end{array}$ \\
\hline
\end{tabular}




\begin{tabular}{|c|c|c|c|c|c|c|c|}
\hline $\begin{array}{l}\text { Lim et al. } \\
2017 \\
\text { (Singapore) }\end{array}$ & $\begin{array}{l}\text { Quasi- } \\
\text { experimental } \\
\text { Pre-test/Post- } \\
\text { test with } 1 \\
\text { group only }\end{array}$ & $\begin{array}{l}\text { 1. To assess } \\
\text { knowledge and } \\
\text { attitudes towards } \\
\text { cervical cancer, } \\
\text { human } \\
\text { papillomavirus } \\
\text { and the HPV } \\
\text { vaccination } \\
\text { before and after } \\
\text { the intervention. }\end{array}$ & $\begin{array}{l}\text { Age: 15-19 } \\
\text { years (99.3\%) } \\
\text { Gender: } \\
\text { Female only } \\
\text { Numbers: } 150 \\
\text { students ( } 1 \\
\text { junior college } \\
\text { only) } \\
\text { One of the top } \\
\text { pre-university } \\
\text { centres in } \\
\text { Singapore so } \\
\text { may not be } \\
\text { very } \\
\text { representative } \\
\text { of the whole } \\
\text { population. }\end{array}$ & Not discussed & $\begin{array}{l}\text { Intervention: a } \\
\text { presentation on } \\
\text { individual } \\
\text { tablets with no } \\
\text { evidence of any } \\
\text { discussion with } \\
\text { the team } \\
\text { members after } \\
\text { the } \\
\text { presentation. } \\
\text { Delivered by } \\
\text { trained } \\
\text { members of the } \\
\text { research team } \\
\text { though unclear } \\
\text { Q\&A } \\
\text { opportunity. } \\
\text { Intervention } \\
\text { lasted } 10 \\
\text { minutes on } \\
\text { average. }\end{array}$ & $\begin{array}{l}\text { A baseline } \\
\text { questionnaire } \\
\text { was } \\
\text { completed. } \\
\text { A second post- } \\
\text { intervention } \\
\text { questionnaire } \\
\text { was } \\
\text { completed } \\
\text { directly after } \\
\text { the } \\
\text { intervention. }\end{array}$ & $\begin{array}{l}\text { 1. The intervention } \\
\text { resulted in raised } \\
\text { awareness and } \\
\text { knowledge in most } \\
\text { aspects with regards } \\
\text { to HPV, HPV vaccine } \\
\text { and Pap smears to } \\
\text { prevent cervical } \\
\text { cancer. } \\
\text { 2. Increased intention } \\
\text { to be vaccinated was } \\
\text { also found after the } \\
\text { intervention. }\end{array}$ \\
\hline $\begin{array}{l}\text { Yoost et al. } \\
2017 \\
\text { ( USA) }\end{array}$ & $\begin{array}{l}\text { Quasi- } \\
\text { experimental } \\
\text { Pre-test/Post- } \\
\text { test with } 1 \\
\text { group only }\end{array}$ & $\begin{array}{l}\text { 1. To evaluate the } \\
\text { use of telehealth } \\
\text { as a tool for } \\
\text { teaching } \\
\text { reproductive } \\
\text { health. } \\
\text { 2. To evaluate } \\
\text { changes in } \\
\text { student } \\
\text { knowledge and }\end{array}$ & $\begin{array}{l}\text { Age: Average } \\
16.1 \text { (range } \\
\text { 14-18 years) } \\
\text { Gender: } \\
\text { Females only } \\
\text { Numbers: } 26 \\
\text { students } \\
\text { completed the } \\
\text { initial pre and }\end{array}$ & Not discussed & $\begin{array}{l}\text { Intervention: A } 1 \\
\text { hour after } \\
\text { school } \\
\text { telehealth } \\
\text { session detailing } \\
\text { types of STDs } \\
\text { and modes of } \\
\text { transmission, } \\
\text { long-term } \\
\text { complications, } \\
\text { prevention of }\end{array}$ & $\begin{array}{l}\text { Pre- and post- } \\
\text { intervention } \\
\text { questionnaires } \\
\text { were } \\
\text { completed at } \\
\text { each session } \\
\text { and were used } \\
\text { to assess } \\
\text { subject } \\
\text { knowledge }\end{array}$ & $\begin{array}{l}\text { 1. A statistically } \\
\text { significant } \\
\text { change in knowledge } \\
\text { was seen regarding } \\
\text { human papillomavirus } \\
\text { (HPV) and vaccination } \\
\text { knowledge after the } \\
\text { intervention. }\end{array}$ \\
\hline
\end{tabular}




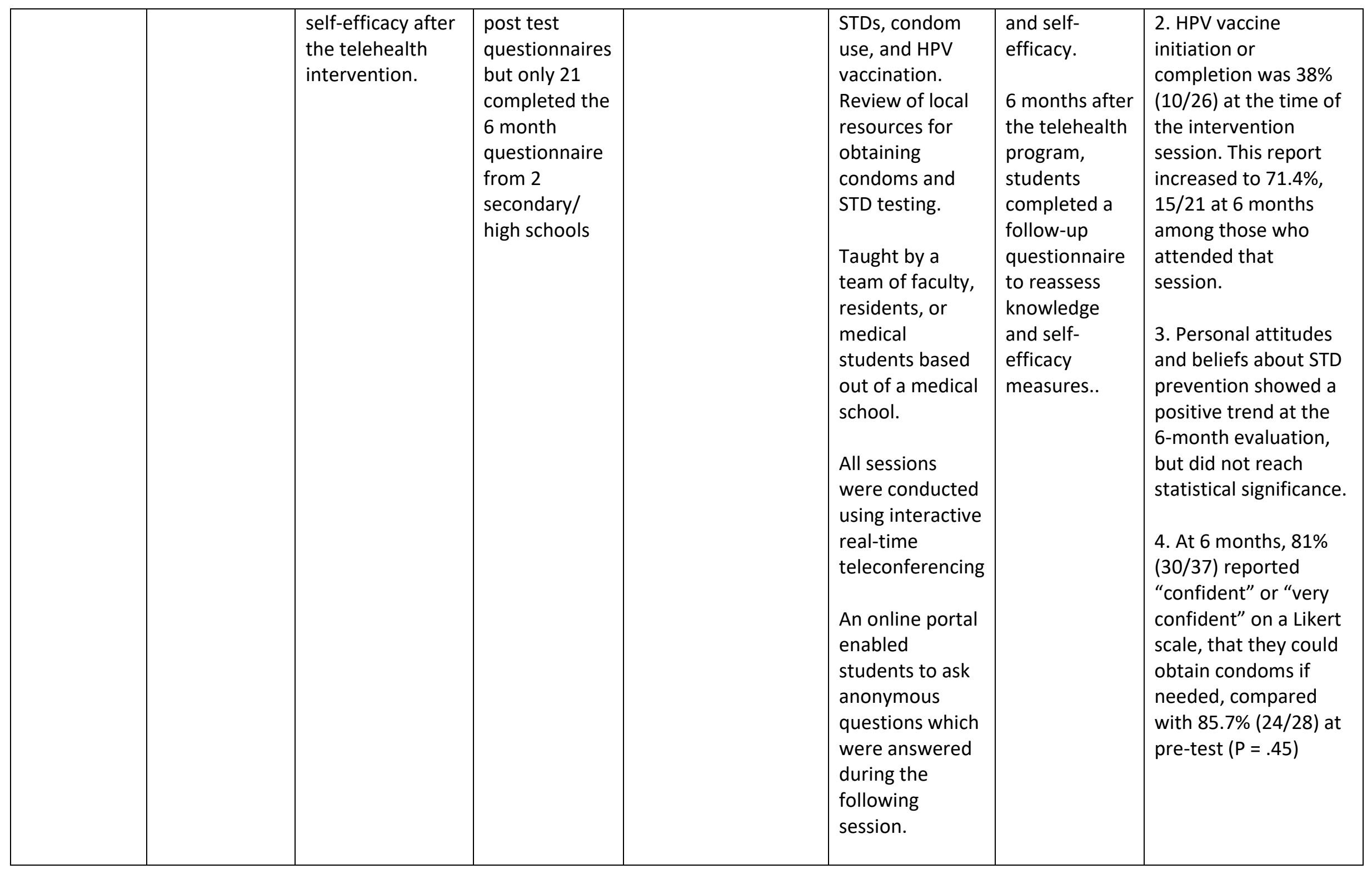




\begin{tabular}{|c|c|c|c|c|c|c|c|}
\hline & & & & & $\begin{array}{l}\text { Financial } \\
\text { incentives were } \\
\text { offered for } \\
\text { participation. }\end{array}$ & & \\
\hline $\begin{array}{l}\text { Grandahl et } \\
\text { al. } 2016 \\
\text { (Sweden) }\end{array}$ & $\begin{array}{l}\text { 2-armed } \\
\text { Cluster RCT }\end{array}$ & $\begin{array}{l}\text { 1. To improve } \\
\text { primary } \\
\text { prevention of } \\
\text { HPV by } \\
\text { promoting HPV } \\
\text { vaccination and } \\
\text { increased } \\
\text { condom use. }\end{array}$ & $\begin{array}{l}\text { Age: } 16 \text { years } \\
\text { only. } \\
\text { Gender: Males } \\
\text { and Females } \\
\text { Numbers: } 18 \\
\text { schools ( } 751 \\
\text { students } \\
\text { recruited with } \\
741 \\
\text { completing } \\
\text { the study) }\end{array}$ & $\begin{array}{l}\text {-Health Belief Model } \\
\text { (HBM) } \\
\text {-The Theory of } \\
\text { Reasoned Action } \\
\text { (TRA) }\end{array}$ & $\begin{array}{l}\text { Arm } 1 \\
\text { (intervention): } \\
\text { School nurses } \\
\text { delivered a face- } \\
\text { to-face } 30 \\
\text { minute } \\
\text { individual } \\
\text { structured and } \\
\text { consistent } \\
\text { interview. } \\
\text { Arm 2: no } \\
\text { structured } \\
\text { teaching }\end{array}$ & $\begin{array}{l}\text { A baseline } \\
\text { questionnaire } \\
\text { was } \\
\text { completed } \\
\text { pre- } \\
\text { intervention } \\
\text { and a second } \\
\text { questionnaire } \\
\text { was } \\
\text { completed } 3 \\
\text { months post- } \\
\text { intervention. } \\
\text { (authors } \\
\text { indicated that } \\
\text { FU may be } \\
\text { done at } 12 \\
\text { and } 24 \\
\text { months } \\
\text { though results } \\
\text { not published } \\
\text { here) }\end{array}$ & $\begin{array}{l}\text { 1. The intervention } \\
\text { had a significant } \\
\text { positive effect on } \\
\text { intention to use } \\
\text { condoms ( } p=0.004 \text { ). } \\
\text { 2. The intervention } \\
\text { had a significant } \\
\text { positive effect on HBM } \\
\text { score ( } p=0.003 \text { ), with a } \\
\text { 2.559 points higher } \\
\text { score for the } \\
\text { intervention group. } \\
\text { 3. HPV vaccination } \\
\text { rates increased to a } \\
\text { higher degree } \\
\text { compared to the } \\
\text { control group ( } p=0.02 \text { ) } \\
\text { 4. There were no } \\
\text { significant differences } \\
\text { between the } \\
\text { intervention and the } \\
\text { control groups } \\
\text { regarding their reports } \\
\text { of actual condom use } \\
\text { during their latest act }\end{array}$ \\
\hline
\end{tabular}




\begin{tabular}{|c|c|c|c|c|c|c|c|}
\hline & & & & & & & $\begin{array}{l}\text { of intercourse } \\
(p=0.377) \text {. }\end{array}$ \\
\hline $\begin{array}{l}\text { Lai et al. } \\
2015 \\
\text { (Taiwan) }\end{array}$ & $\begin{array}{l}\text { A quasi- } \\
\text { experimental } \\
\text { 2-armed study }\end{array}$ & $\begin{array}{l}\text { 1. To identify the } \\
\text { effectiveness of a } \\
\text { Facebook- } \\
\text { assisted teaching } \\
\text { method for a } \\
\text { school-based } \\
\text { intervention on } \\
\text { knowledge and } \\
\text { attitudes about } \\
\text { cervical cancer } \\
\text { prevention and } \\
\text { on HPV } \\
\text { vaccination } \\
\text { intention. }\end{array}$ & $\begin{array}{l}\text { Age: } 15-17 \\
\text { years old } \\
\text { Gender: } \\
\text { Females only } \\
\text { Numbers: } \\
1 \text { school (200 } \\
\text { students) } \\
\text { (4 classes } \\
\text { selected out of } \\
16 \text { classes) }\end{array}$ & $\begin{array}{l}\text { - Health Belief Model } \\
\text { (HBM) }\end{array}$ & $\begin{array}{l}\text { All } 200 \\
\text { participants had } \\
\text { a } 50 \text { min lecture } \\
\text { with brief } \\
\text { discussion } \\
\text { delivered by a } \\
\text { nursing teacher. } \\
\text { Arm } 1 \\
\text { (intervention): } \\
\text { Over the next } 2 \\
\text { weeks this } 100 \\
\text { students then } \\
\text { had the option } \\
\text { of entering } \\
\text { facebook } \\
\text { discussions. } \\
\text { Arm } 2 \text { (control): } \\
\text { Over the next } 2 \\
\text { weeks this } 100 \\
\text { students then } \\
\text { had the option } \\
\text { of entering face- } \\
\text { to-face } \\
\text { discussions. } \\
72 \text { out of } 100 \\
\text { attended } \\
\text { facebook } \\
\text { discussions but } \\
\text { no indication of }\end{array}$ & $\begin{array}{l}\text { A baseline } \\
\text { questionnaire } \\
\text { was } \\
\text { completed by } \\
\text { all students } \\
\text { pre-education } \\
\text { A second } \\
\text { questionnaire } \\
\text { was } \\
\text { completed } 2 \\
\text { weeks post- } \\
\text { lecture. } \\
\text { A third } \\
\text { questionnaire } \\
\text { was } \\
\text { completed } 8 \\
\text { weeks post- } \\
\text { lecture. }\end{array}$ & $\begin{array}{l}\text { 1. Knowledge, attitude } \\
\text { and intention to } \\
\text { vaccinate were all } \\
\text { better in the } \\
\text { intervention arm } \\
\text { though improvements } \\
\text { were noted in both } \\
\text { arms from baseline. } \\
\text { 2. The intervention } \\
\text { group outcomes } \\
\text { remained significantly } \\
\text { higher than those in } \\
\text { the control group at } \\
\text { least } 8 \text { weeks after the } \\
\text { lecture. }\end{array}$ \\
\hline
\end{tabular}




\begin{tabular}{|c|c|c|c|c|c|c|c|}
\hline & & & & & $\begin{array}{l}\text { number of } \\
\text { students who } \\
\text { engaged in face- } \\
\text { to-face } \\
\text { discussions. }\end{array}$ & & \\
\hline $\begin{array}{l}\text { Gargano et } \\
\text { al. } 2014 \\
\text { (USA) }\end{array}$ & $\begin{array}{l}\text { Quasi- } \\
\text { experimental } \\
\text { 3-armed study }\end{array}$ & $\begin{array}{l}\text { 1. To increase } \\
\text { adolescent } \\
\text { vaccination rates } \\
\text { 2. To assess } \\
\text { changes in } \\
\text { knowledge and } \\
\text { attitudes towards } \\
\text { HPV vaccination } \\
\text { after participating } \\
\text { in the } \\
\text { intervention }\end{array}$ & $\begin{array}{l}\text { Age: } 11-18 \\
\text { years old } \\
\text { Gender: } \\
\text { Females only } \\
\text { Numbers: } 15 \\
\text { schools (1068 } \\
\text { students) }\end{array}$ & $\begin{array}{l}\text {-Health Belief Model } \\
\text { (HBM) }\end{array}$ & $\begin{array}{l}\text { Arm } 1 \text { (control): } \\
\text { no intervention } \\
\text { Arm 2: Approx. } \\
120 \text { minutes } \\
\text { over 2-3 days } \\
\text { with a variety of } \\
\text { interactive } \\
\text { activities but } \\
\text { done } \\
\text { consistently. } \\
\text { Science } \\
\text { Teachers } \\
\text { delivered the } \\
\text { education. } \\
\text { A specially } \\
\text { constructed } \\
\text { brochure was } \\
\text { also sent to } \\
\text { parents who } \\
\text { participated in } \\
\text { Arm 2. } \\
\text { Arm 3: Parent } \\
\text { directed } \\
\text { brochure only. }\end{array}$ & $\begin{array}{l}\text { A baseline } \\
\text { questionnaire } \\
\text { was } \\
\text { completed } \\
\text { pre- } \\
\text { intervention } \\
\text { and a second } \\
\text { questionnaire } \\
\text { was } \\
\text { completed } 3 \\
\text { days post- } \\
\text { intervention. }\end{array}$ & $\begin{array}{l}\text { 1. The intervention } \\
\text { group (Arm } 2 \text { ) showed } \\
\text { an increase in interest } \\
\text { in receiving HPV } \\
\text { vaccine post- } \\
\text { intervention. } \\
\text { 2. The intervention } \\
\text { group (Arm } 2 \text { ) showed } \\
\text { improved knowledge } \\
\text { and attitudes relating } \\
\text { to HPV vaccination } \\
\text { post-intervention } \\
\text { ( } p<0.001 \text { ). }\end{array}$ \\
\hline
\end{tabular}




\begin{tabular}{|c|c|c|c|c|c|c|c|}
\hline $\begin{array}{l}\text { Steckelberg } \\
\text { et al. } 2013 \\
\text { (Germany) }\end{array}$ & 2-armed RCT & $\begin{array}{l}\text { 1. To compare } \\
\text { the effects of an } \\
\text { information } \\
\text { leaflet including } \\
\text { numerical data to } \\
\text { standard } \\
\text { information } \\
\text { without } \\
\text { numerical data on } \\
\text { 'risk knowledge' } \\
\text { regarding HPV } \\
\text { vaccination in } \\
\text { disadvantaged } \\
\text { school girls of } \\
\text { full-time } \\
\text { vocational } \\
\text { schools. }\end{array}$ & $\begin{array}{l}\text { Age: } 15-22 \\
\text { years old } \\
\text { Gender: } \\
\text { Females only } \\
\text { Numbers: } 3 \\
\text { schools (105 } \\
\text { students) }\end{array}$ & Not discussed. & $\begin{array}{l}\text { Arm } 1 \\
\text { (intervention } \\
\text { arm): } \\
\text { standard leaflet } \\
\text { was } \\
\text { supplemented } \\
\text { with numerical } \\
\text { information on } \\
\text { cancer risk and } \\
\text { on benefit of the } \\
\text { HPV vaccination } \\
\text { in terms of } \\
\text { cancer } \\
\text { prevention. } \\
\text { (No actual } \\
\text { teaching } \\
\text { delivered } \\
\text { though students } \\
\text { were in class for } \\
\text { a } 90 \text { minute } \\
\text { period to review } \\
\text { leaflets.) } \\
\text { Arm 2: Standard } \\
\text { HPV information } \\
\text { leaflet. } \\
\text { After each } \\
\text { intervention, } \\
\text { participants had } \\
\text { Q\&A and } \\
\text { discussion } \\
\text { opportunity. }\end{array}$ & $\begin{array}{l}\text { A baseline } \\
\text { questionnaire } \\
\text { was } \\
\text { completed } \\
\text { pre- } \\
\text { intervention } \\
\text { and a second } \\
\text { questionnaire } \\
\text { was } \\
\text { completed } \\
\text { directly after } \\
\text { the } \\
\text { intervention. }\end{array}$ & $\begin{array}{l}\text { 1. Risk knowledge was } \\
\text { better in the modified } \\
\text { leaflet group } \\
\text { (intervention group). }\end{array}$ \\
\hline
\end{tabular}




\begin{tabular}{|c|c|c|c|c|c|c|c|}
\hline $\begin{array}{l}\text { Marek et al. } \\
2012 \\
\text { (Hungary) }\end{array}$ & $\begin{array}{l}\text { Quasi- } \\
\text { experimental } \\
\text { 2-armed study }\end{array}$ & $\begin{array}{l}\text { 1. To establish } \\
\text { the impact of a } \\
\text { school-based } \\
\text { HPV-focused } \\
\text { intervention on } \\
\text { adolescents' } \\
\text { knowledge, } \\
\text { beliefs and } \\
\text { attitudes towards } \\
\text { the prevention of } \\
\text { HPV infection and } \\
\text { cervical cancer 3- } \\
\text { months following } \\
\text { the program. }\end{array}$ & $\begin{array}{l}\text { Age: 14-19 } \\
\text { years old } \\
\text { Gender: both } \\
\text { males and } \\
\text { females } \\
\text { Numbers: } 2 \\
\text { schools (394 } \\
\text { completed } \\
\text { baseline } \\
\text { questionnaire } \\
\text { and } 378 \\
\text { completed } 3 \\
\text { month post- } \\
\text { test } \\
\text { questionnaire } \\
\text { but they may } \\
\text { not be the } \\
\text { same students } \\
\text { 191 students } \\
\text { attended the } \\
\text { intervention in } \\
\text { total. }\end{array}$ & Not discussed & $\begin{array}{l}\text { One school was } \\
\text { the control and } \\
\text { other school the } \\
\text { intervention. } \\
\text { Arm } 1 \\
\text { (intervention): A } \\
\text { trained health } \\
\text { educator ( } 1^{\text {st }} \\
\text { author) } \\
\text { delivered the } \\
\text { intervention. } \\
\text { Education in } 8 \\
\text { classes ( } 25-33 \\
\text { students in each } \\
\text { class). } \\
45 \text { min didactic } \\
\text { presentation } \\
\text { followed by } \\
\text { Q\&A and } \\
\text { handouts. } \\
\text { Arm } 2 \text { (control): } \\
\text { No education } \\
\text { provided. }\end{array}$ & $\begin{array}{l}\text { Both groups } \\
\text { conducted } \\
\text { baseline } \\
\text { questionnaires } \\
\text { and a second } \\
\text { questionnaire } \\
3 \text { months after } \\
\text { the } \\
\text { intervention. }\end{array}$ & $\begin{array}{l}\text { 1. Results confirm that } \\
\text { female students had } \\
\text { higher baseline } \\
\text { knowledge of HPV and } \\
\text { cervical cancer } \\
\text { compared to males. } \\
\text { 2. Both genders in the } \\
\text { intervention group } \\
\text { demonstrated } \\
\text { significant } \\
\text { improvement in } \\
\text { knowledge, attitude } \\
\text { and intention to be } \\
\text { vaccinated despite } \\
\text { financial barriers in } \\
\text { comparison to the } \\
\text { control group. }\end{array}$ \\
\hline $\begin{array}{l}\text { Merzouk et } \\
\text { al. } 2011 \\
\text { (USA) }\end{array}$ & 2-armed RCT & $\begin{array}{l}\text { 1. To assess } \\
\text { baseline and } \\
\text { post-intervention } \\
\text { knowledge of } \\
\text { HPV. }\end{array}$ & $\begin{array}{l}\text { Age: Not } \\
\text { stated but } \\
\text { likely 14-18 } \\
\text { years old. } \\
\text { Gender: Not } \\
\text { stated but }\end{array}$ & Not discussed. & $\begin{array}{l}\text { Arm } 1 \\
\text { (intervention): } \\
15 \text { minute HPV } \\
\text { DVD educational } \\
\text { intervention } \\
\text { plus standard } \\
\text { health class }\end{array}$ & $\begin{array}{l}\text { Questionnaire } \\
\text { at baseline } \\
\text { (pre- } \\
\text { education) } \\
\text { and directly } \\
\text { after } \\
\text { intervention. }\end{array}$ & $\begin{array}{l}\text { 1. Improvement in } \\
\text { knowledge was } \\
\text { significantly better in } \\
\text { the DVD (intervention) } \\
\text { group }(P<.0001) \\
\text { compared to the } \\
\text { control group. }\end{array}$ \\
\hline
\end{tabular}




\begin{tabular}{|c|c|c|c|c|c|c|c|}
\hline & & & $\begin{array}{l}\text { possibly } \\
\text { females only } \\
\text { as information } \\
\text { is generally } \\
\text { focused on } \\
\text { cervical cancer } \\
\text { Numbers: } 626 \\
\text { participants } \\
\text { completed the } \\
\text { study }\end{array}$ & & $\begin{array}{l}\text { scheduled over } \\
2 \text { days. Content } \\
\text { of DVD is not } \\
\text { very clear. } \\
\text { Arm 2: Control. } \\
\text { Standard health } \\
\text { class only } \\
\text { (Health classes } \\
\text { were delivered } \\
\text { by teachers.) }\end{array}$ & & \\
\hline $\begin{array}{l}\text { Kwan et al. } \\
2011 \\
\text { (Hong Kong) }\end{array}$ & $\begin{array}{l}\text { Quasi- } \\
\text { experimental } \\
\text { Pre-test/Post- } \\
\text { test with } 1 \\
\text { group only }\end{array}$ & $\begin{array}{l}\text { To evaluate the } \\
\text { effects of a } \\
\text { school-based } \\
\text { cervical cancer } \\
\text { education } \\
\text { intervention on; } \\
\text { 1. knowledge, } \\
\text { attitude and } \\
\text { perceived social } \\
\text { norms towards } \\
\text { HPV vaccination. } \\
\text { 2. students' } \\
\text { intention to be } \\
\text { vaccinated. }\end{array}$ & $\begin{array}{l}\text { Age: } 12-17 \\
\text { years old } \\
\text { Gender: } \\
\text { Females only } \\
\text { Numbers: } 4 \\
\text { schools (953 } \\
\text { students } \\
\text { completed the } \\
\text { study) }\end{array}$ & $\begin{array}{l}\text { - Theories of } \\
\text { persuasion }\end{array}$ & $\begin{array}{l}\text { Intervention: } \\
\text { Didactic slide } \\
\text { presentation } \\
\text { delivered by a } \\
\text { gynecological } \\
\text { oncologist } \\
\text { followed by an } \\
\text { interactive Q\&A } \\
\text { session lasting } \\
1 \text { hr in total. } \\
\text { (large groups } \\
\text { ranging from } \\
179 \text { to } 426 \text { girls) } \\
\text { Information } \\
\text { sheet provided } \\
\text { prior to teaching } \\
\text { session. }\end{array}$ & $\begin{array}{l}\text { A baseline } \\
\text { questionnaire } \\
\text { was } \\
\text { completed } \\
\text { pre- } \\
\text { intervention } \\
\text { and a second } \\
\text { questionnaire } \\
\text { was } \\
\text { completed } \\
\text { directly after } \\
\text { the } \\
\text { intervention. }\end{array}$ & $\begin{array}{l}\text { 1. Increase in } \\
\text { knowledge, more } \\
\text { positive attitude } \\
\text { towards HPV } \\
\text { vaccination and } \\
\text { increased perceived } \\
\text { support from family } \\
\text { and peers were } \\
\text { evident after the } \\
\text { intervention. } \\
\text { 2. More students } \\
\text { indicated a positive } \\
\text { intention to accept the } \\
\text { vaccine after the } \\
\text { intervention. }\end{array}$ \\
\hline
\end{tabular}




\begin{tabular}{|c|c|c|c|c|c|c|c|}
\hline $\begin{array}{l}\text { Gottvall et } \\
\text { al. } 2010 \\
\text { (Sweden) }\end{array}$ & $\begin{array}{l}\text { A quasi- } \\
\text { experimental } \\
\text { 2-armed } \\
\text { study. }\end{array}$ & $\begin{array}{l}\text { 1. To evaluate the } \\
\text { effect of an } \\
\text { educational } \\
\text { intervention } \\
\text { about HPV and } \\
\text { preventive } \\
\text { methods for } \\
\text { cervical cancer, } \\
\text { such as } \\
\text { vaccination, } \\
\text { condom use and } \\
\text { Pap smear testing } \\
\text { on knowledge of } \\
\text { HPV and attitudes } \\
\text { to preventive } \\
\text { methods. }\end{array}$ & $\begin{array}{l}\text { Age: Mean age } \\
16 \text { years } \\
\text { though the } \\
\text { range was not } \\
\text { stated but all } \\
\text { in } 1^{\text {st }} \text { year of } \\
\text { high school } \\
\text { Gender: both } \\
\text { males and } \\
\text { females } \\
\text { Numbers: } \\
6 \text { schools ( } 276 \\
\text { students) } \\
\text { (A strategic } \\
\text { sample of first } \\
\text { year students } \\
\text { from both } \\
\text { vocational and } \\
\text { theoretical } \\
\text { high school } \\
\text { programmes) }\end{array}$ & $\begin{array}{l}\text { - Health Belief Model } \\
\text { (HBM) }\end{array}$ & $\begin{array}{l}2 \text { control groups } \\
\text { to assess } \\
\text { whether pre } \\
\text { intervention } \\
\text { questionnaire } \\
\text { affected } \\
\text { outcome. } \\
\text { Arm } 1 \\
\text { (intervention): A } \\
\text { Registered nurse } \\
\text { (who was also } \\
\text { one of the } \\
\text { research } \\
\text { authors) } \\
\text { delivered a } 1 \mathrm{hr} \\
\text { lesson plan ( } 20 \\
\text { mins lecture, } \\
\text { condom } \\
\text { demonstration } \\
\text { and practice, } \\
\text { wrap-up } \\
\text { discussion and } \\
\text { take away folder } \\
\text { with link to } \\
\text { website to } \\
\text { complete } \\
\text { activities) } \\
\text { Arm } 2+3 \\
\text { (controls): No } \\
\text { lesson plan }\end{array}$ & $\begin{array}{l}\text { A baseline } \\
\text { questionnaire } \\
\text { was } \\
\text { completed by } \\
\text { all students } \\
\text { pre- } \\
\text { intervention } \\
\text { and a second } \\
\text { questionnaire } \\
\text { was } \\
\text { completed } \\
\text { directly after } \\
\text { the } \\
\text { intervention. }\end{array}$ & $\begin{array}{l}\text { 1. At follow-up, the } \\
\text { median knowledge } \\
\text { score had significantly } \\
\text { increased in the } \\
\text { intervention group but } \\
\text { not in the comparison } \\
\text { group ( } P<0.001) \text {. } \\
\text { 2. Attitudes to HPV } \\
\text { vaccination, condom } \\
\text { use and Pap smear } \\
\text { testing remained the } \\
\text { same ( } P>0.05) \text {. This } \\
\text { may be due to a } \\
\text { positive baseline } \\
\text { attitude. }\end{array}$ \\
\hline
\end{tabular}




\begin{tabular}{|c|c|c|c|c|c|c|c|}
\hline $\begin{array}{l}\text { Lloyd et al. } \\
2009 \\
\text { (UK) }\end{array}$ & $\begin{array}{l}\text { A quasi- } \\
\text { experimental } \\
\text { 3-armed } \\
\text { study. }\end{array}$ & $\begin{array}{l}\text { 1. To assess effect } \\
\text { of } \\
\text { HPV information } \\
\text { on knowledge } \\
\text { and anxiety. } \\
\text { 2. To assess } \\
\text { future intentions } \\
\text { to participate } \\
\text { in cervical } \\
\text { screening, HPV } \\
\text { testing, and } \\
\text { HPV vaccination a } \\
\text { fter this } \\
\text { intervention. }\end{array}$ & $\begin{array}{l}\text { Age: } 13-16 \\
\text { years old } \\
\text { Gender: } \\
\text { Female only } \\
\text { Numbers: } \\
2 \text { schools with } \\
174 \text { students } \\
\text { recruited ( } 2 \text { of } \\
\text { these students } \\
\text { were } \\
\text { excluded) }\end{array}$ & $\begin{array}{l}\text { - Leventhal's } \\
\text { Common Sense } \\
\text { Model of lay illness } \\
\text { representations. }\end{array}$ & $\begin{array}{l}\text { Arm } 1 \\
\text { (intervention): } \\
\text { Leaflet with } \\
\text { HPV, Chlamydia } \\
\text { and } \\
\text { environmental } \\
\text { information } \\
\text { Arm } 2 \text { (control): } \\
\text { Leaflet with } \\
\text { Chlamydia } \\
\text { information only } \\
\text { Arm } 3 \text { (control): } \\
\text { Leaflet with } \\
\text { environmental } \\
\text { information } \\
\text { only. } \\
\text { Students were } \\
\text { given } 5 \text { minutes } \\
\text { to read each } \\
\text { leaflet. }\end{array}$ & $\begin{array}{l}\text { No baseline } \\
\text { questionnaire } \\
\text { was provided } \\
\text { Questionnaire } \\
\text { was } \\
\text { completed } \\
\text { directly after } \\
\text { reading the } \\
\text { leaflets. } \\
\text { Knowledge } \\
\text { was assessed } \\
\text { using true or } \\
\text { false } \\
\text { statements } \\
\text { about HPV, } \\
\text { and anxiety } \\
\text { using the six- } \\
\text { item State- } \\
\text { Trait Anxiety } \\
\text { Inventory } \\
\text { (STAI). }\end{array}$ & $\begin{array}{l}\text { 1. The Intervention } \\
\text { group demonstrated } \\
\text { significantly more } \\
\text { HPV knowledge } \\
(p<.001) \text { than } \\
\text { controls post- } \\
\text { intervention. } \\
\text { 2. Intentions to attend } \\
\text { cervical screening and } \\
\text { accept } \\
\text { HPV vaccination were } \\
\text { highest in intervention } \\
\text { group intentions } \\
\text { 3. Intentions to have } \\
\text { HPV testing were } \\
\text { equally high in all } \\
\text { groups. }\end{array}$ \\
\hline
\end{tabular}

Table 1: Study Properties 


\begin{tabular}{|c|c|c|c|c|c|c|c|c|c|}
\hline & $\begin{array}{l}\text { Selection } \\
\text { bias }\end{array}$ & $\begin{array}{l}\text { Study } \\
\text { Design }\end{array}$ & Confounders & Blinding & $\begin{array}{l}\text { Data } \\
\text { Collection } \\
\text { Methods }\end{array}$ & $\begin{array}{l}\text { Withdrawal } \\
\text { and dropout }\end{array}$ & $\begin{array}{l}\text { Intervention } \\
\text { Integrity }\end{array}$ & $\begin{array}{l}\text { Analysis } \\
\text { Appropriate } \\
\text { to Question }\end{array}$ & $\begin{array}{l}\text { Total Rating } \\
\text { (Score out of } \\
16)\end{array}$ \\
\hline Ali et al. & Moderate & Moderate & Moderate & Weak & Strong & Moderate & Weak & Strong & Moderate (8) \\
\hline Sadoh et al. & Weak & Moderate & Strong & Weak & Moderate & Strong & Weak & Strong & Moderate (8) \\
\hline Ifediora et al. & Moderate & Moderate & Weak & Weak & Moderate & Strong & Weak & Moderate & Moderate (6) \\
\hline Davies et al. & Strong & Strong & Strong & Strong & Moderate & Weak & Strong & Strong & Strong (13) \\
\hline Lim et al. & Moderate & Moderate & Weak & Weak & Weak & Moderate & Weak & Strong & Weak (5) \\
\hline Yoost et al. & Weak & Moderate & Strong & Strong & Weak & Moderate & Strong & Strong & Moderate (10) \\
\hline Grandahl et al. & Strong & Strong & Moderate & Weak & Strong & Strong & Strong & Strong & Strong (13) \\
\hline Lai et al. & Moderate & Moderate & Strong & Weak & Strong & Weak & Moderate & Strong & Moderate (9) \\
\hline Gargano et al. & Moderate & Moderate & Weak & Weak & Moderate & Weak & Strong & Strong & Moderate (7) \\
\hline Steckelberg et al. & Moderate & Strong & Moderate & Strong & Moderate & Strong & Moderate & Strong & Strong (12) \\
\hline Marek et al. & Moderate & Strong & Strong & Weak & Moderate & Strong & Moderate & Strong & Strong (11) \\
\hline Merzouk et al. & Moderate & Moderate & Weak & Weak & Moderate & Moderate & Weak & Strong & Moderate (6) \\
\hline Kwan et al. & Moderate & Moderate & Moderate & Weak & Moderate & Strong & Moderate & Strong & Moderate (9) \\
\hline Gottvall et al. & Moderate & Strong & Moderate & Moderate & Strong & Moderate & Strong & Strong & Strong (12) \\
\hline Lloyd et al. & Moderate & Moderate & Weak & Weak & Moderate & Strong & Moderate & Strong & Moderate (8) \\
\hline
\end{tabular}

Table 2: Quality Assessment Tool for Quantitative Studies rating for eligible studies. 'Strong' was allocated a score of 2. 'Moderate' a score of 1. 'Weak' a score of zero. [Studies were referred to as strong if score $>10$, Moderate 6-10 and Weak $\leq 5$ ] 